\title{
Dalit Assertion and Its Concomitant Impact on Rural Society of Bihar
}

\author{
Upendra Kunwar \\ Principal, Langat Singh College, Muzaffarpur, Bihar, India
}

\begin{abstract}
Indian social structure has its unique place in the world, primarily because of its caste system. In the post -colonial era, traditional Indian rural society has undergone a change due to democratic value system, urbanization, modernization, faster growth of secondary and tertiary sectors, changing occupational structures, constitutional and legal measures for protective discrimination, rising level of literacy, etc. Indian constitution, in principal, is committed to the doctrine of socio-economic and political Justice to every Indian citizen. Successive government started socially desirable and economically viable developmental measures to assure and protect Equality of opportunity and dignity of every individual, and furthers 'participatory development'. But all social groups have not benefited equally in last sixty nine years. Social and economic inequality still occupies the centre-stage of Indian reality. The ideals of social democracy and distributive justice, in their essence, remain elusive. On the contrary, the vast majority of the Indian population is deprived socially, economically, politically and educationally. Scheduled caste (dalit, used in exclusive sense of the term) is designated as 'disadvantaged group' of our society even today. A stock taking of the status of dalit reveals that the problem of dignity and freedom from poverty, illiteracy, unemployment remain unresolved in spite of variety of measures taken by the central and state government for their welfare and dignified life chances.
\end{abstract}

Key Words: Participatory development, Social democracy and distributive justice, Disadvantaged group

\section{Introduction}

In post colonial era, customary Indian rural society has pass through a change due to democratic value system, urbanization, modernization, rapid growth of secondary and tertiary sector, varying occupational structures, Constitutional and legal measures for protective discrimination, rising level of literacy, etc. Indian Constitution, in principle, is committed to the doctrine of socio-economic and political justice to every Indian citizen. Successive government started socially desirable and economically viable developmental measures to assure and protect Equality of opportunity and dignity of every individual, and further "participatory development". But all social groups have not benefited equally in last sixty-six years. Scheduled caste (Dalit, used in exclusive sense of the term is a Sanskrit word, can be used both a noun and an adjective for all three genders, masculine, feminine, and neuter. It has been derived from the root "Dal" which means to crack, open, split etc. when used as an adjective it means burst, split broken or torn, asunder, down trodden, scattered, crushed, destroyed etc. constitutionally the word scheduled caste is used instead of Dalit. ${ }^{1}$ ) is designated as disadvantage group of our society even today. A Stocktaking on the status of Dalit reveal that the problem of dignity and freedom from poverty, illiteracy, unemployment remain unresolved whereas the new development of hierarchical class depicts among them, growing concernment in politics, free to choose occupation, fearless practice of religious rituals. Moreover, the movements and rising of self consciousness brought about social solidarity within the Dalit community in spite of the fact that the community itself riddles with the same value judgment of comparative impurity. The most important aspect of this journey now is that Dalits could gain some capacity and confidence to engage in making confrontational identity contrary to the traditional identity of untouchables. This creates a sort of social development in many dimensions and paves a moral and psychological way to be more dependent on economic structure other than local rural structure and economy. Although this has severely attacked the super-structure (social, economic and political structure) of caste system but yet Dalits could not go beyond the scope of Human Rights that regularly questions the human freedom and choice of scientific and economic development in the state of Bihar.

\footnotetext{
${ }^{1}$ Massey James, Indigenous People Dalit, ISPCK, New Delhi, 1998, P- 6, ISBN: 81-7214-154-8
} 
However; under the impact of emerging new socio-economic and political forces, dalit assertion has emerged as a social fact in the state of Bihar. Assertion is defined as a positive declaration about oneself, one's past, present and future. The assertion also informed the others of the society about one's resolve and their course of action. It is here that dalit assertion confronts resistance and repression from the dominant castes and classes. The process of assertion also provides path for emancipation of dalits. All these process depicts the new formation in rural social arena in Bihar. The term "Social formation" was devised by structuralist Marxist Louis Althusser as a substitute for society. For Althusser, a social formation is a complex of concrete economic, political, and ideological relations, bound together and given their particular character as capitalist, feudal, or whatever by the fact that the economic relations are, in his word, 'determinant in the last instance'. Along with this, it includes all the internal contradictions that exist in a society, all emerging and disappearing tendencies in the economy and superstructure, in the social relationships that comprise these. In Addition, One defining element of a social formation is the emerging tendency of mode of production (what is arising vs. what is declining). The concept also refers to all the social classes and the intricate contradictory unity of their relations, which constitute the structure of class struggle and which are detectable by class struggle. This includes the way classes express (politically and ideologically) their concepts for reproduction. Each class has a resistance to its own disappearance and struggles to continue to exist, to reproduce itself. However, the forms of reproduction of a social formation influence how the superstructure takes shape- in that the dominant modes of production interact with and affect the superstructure in ways that facilitate their own reproduction. A social formation materially manifested as the totality of the relations of classes at all levels: the relations of production and circulation (including those which are not directly economic but produce an economic effect), and of the superstructure (political, judicial and ideological relations). Sudha Pai (2002) in her comprehensive study of dalit argues that the state has experienced three major attempts by the dalit to improve their socio-economic status and increase their share in political power. The first was during colonial period, when the Chamar-Jatav (numerically powerful and socially mobile dalit sub-caste) renounced the Gandhian ideals under the influence of Ambedkar. Earlier they had made an attempt to rise in the caste hierarchy through sanskritisation. Whereas, Dalit status has often been historically associated with occupations regarded as ritually impure such as involving in leatherwork, butchering or removal of rubbish, animal carcasses, and waste. Dalit work as manual laborers, scavenger, cleaning streets, latrines and sewers engaging in these activities were considered to be polluting to the individual and this pollution was considered contagious. Dalit were commonly segregated, and banned from full participation in Hindu social life. From many kinds of religious, economic and social discrimination they were neither allowed to study the sacred scriptures nor permitted to worship in the temple of Hindu, even their touch was considered defiling by Hindu and hence they were not allowed to draw water from tanks and wells of the latter. Apart from this ban on any direct contact, they were forbidden to build house of bricks, to use an umbrella or footwear. Their women were obliged not to cover their breasts. They were restricted in dress, speech, food and manner. ${ }^{2}$

Presently, Dalit affirmation in the state has taken two forms in recent years- first, voting and supporting regional political parties, which raised their political awareness and increased their political participation. Second, new forms of socio-economic activities at the grassroots, which include education their children, prohibiting child marriage, adopting family planning, changing traditional occupation, migrating to urban areas, improving health status, etc. the dalits have made an attempt to improve their living standards, compete with upper castes in all walks of life, and register their protest against all forms of exploitation and domination. All these factors have obvious impact on the traditional rural structure of Bihar. Rising level of literacy and exposure to modern values; due to migration in the more modern non-rural world, have not only increased their sense of existence and self-identity, but also posed the question of distributive justice and sense of relative deprivation.

The above issues are intricately linked in complex ways and determine the course of social dynamics of rural Bihar. However; Bihar has achieved significant growth and development. It has been successful in reducing poverty and improving crucial human development indicators (HDI), such as level of literacy, income level and health. Scheduled castes, which constitute $16.2 \%$ of the state's population, lag behind in terms of most of the HDI. Serious attempts have been made by the Govt. of Bihar through policy initiatives and developmental measures, to ameliorate the conditions of this community, hence, declared some of the caste as Mahadalit within Dalit caste and made a commission in 2007. Dalit have made some perceptible progress in socio-economic and

\footnotetext{
${ }^{2}$ Murugkar Lata, Dalit Panther Movement in Maharashtra- A Sociological appraisal, Sangam Books Ltd, 1991, P-6
} 
political spheres, but fact remains that the gap among dalit as Sachchidanand (1977) states that the Dakhinaha chamar maintain distance from other chamar and mochi ${ }^{3}$; Dusadh are endogamous groups and do not take cooked food from each other's (sub- caste) hand ${ }^{4}$; The Magahia and Trihutia musahar do not inter-marry ${ }^{5}$; Dhobi, Dusadh, Paasi still practices distance to other Dalit caste has widened over the years.

These dynamic scenarios depict the new dimensions of socio- economic change among Dalit, which seems that its impact is structuring a new social formation in rural area, in spite of all the contradiction of the traditional relationship.

\section{Notes:}

[1] Alexander, K.C, 1968: Social Mobility in Kerala, Uppal Publishing House, Delhi

[2] Ambedkar, B.R, 1946: Who Were the Sudras? Thackers Publications, Bombay

[3] Ambedkar, B.R, 1948: The Untuchables, Amrit Book Co., New Delhi

[4] Bhatnagar, A., 1990: A Scheduled Caste in an Urban Setting: The Jatav-Chamars of Dehra Dun City, Uppal Publishing House, Delhi

[5] Briggs, G.W., 1920: The Chamars, London

[6] Danda, A.K.,1993: Weaker Sections in Indian Villages, Inter India Publishing, New Delhi

[7] Kumar, Vivek, 2006: India's Roaring Revolution: Dalit Assertion and New Horizons, Eastern Book Corporation, New Delhi

[8] Lal, A.K and Tiwari, S.N., 1977: The Harijan Elite, Thompson Press, Faridabad

[9] Massey, J., 1995: Dalit in India, Manohar Publication, Delhi

[10] Mukherjee, A.B., 1980: The Chamars of Uttar Pradesh, Leeladevi Publication, New Delhi

[11]Pai, Sudha, 2002: Dalit Assertion and the Unfinished Democratic Revolution: The Bahujan Samaj Party in Uttar Pradesh, Sage Publication, New Delhi

[12] Pai Sudha, 2002: Political Process in Uttar Pradewh: Identity, Economic Reforms and Governance, Pearson-Longman, New Delhi

[13] Patwardhan, S., 1959: Changes among India's Harijan, Orient Longman, New Delhi

[14] Sharma, N., 1985: Untouchables in Rural Gujarat, Popular Prakashan, Bombay

[15] Singh D.R., 1985: Rural Leadreship among Scheduled Castes, Chagh Pub., Allahabad

[16] Thorat, S., 2009: Dalit in India: Search for a Common Destiny, Sage Publication, New Delhi https://doi.org/10.4135/9788132101086

[17] Tiwari, B.N., 2011: Making of the Dalit Public in North India, The Uttar Pradesh, 1950-Present Oxford University Press, New Delhi

[18] Tripathi, R.B., 1994: Dalit : A Sub-Human Society, Ashish Publishing House, Delhi

[19] Yadav, S.K., 1983: Harijan Awareness of Educational Schemes, Academy Press, Gurgaon

[20] Murugkar, Lata: Dalit Panther Movement in Maharashtra- A Sociological appraisal, Sangam Books Ltd, 1991

[21] Ambedkar,B.R: The untouchable: who were they? And why they became untouchaqble, Bheem Patrika Publications, Jalandhar, 1948

[22] Isaacs, H.R: India's Ex- Untouchables, Asia Publishing House, 1964

[23] Sachchidananda, The Harijan Elite, Thomson Press(India) Ltd., 1977

[24] Ambedkar and Social Justice- Vol. I, Publications Division, Ministry of Information and Broadcasting, Govt. of India, 1992

[25] Freeman, J.M: Untouchable, Stanford University Press, California, 1989

[26] Singh, Hoshiar and Malik, A.S: Socio- Economic Development of Scheduled cast in India, Aalekh Publishers, Jaipur, 2001

\footnotetext{
${ }^{3}$ Sachchidananda , Harijan Elite, Thomson Press (india) ltd. 1977, P- 18

${ }^{4}$ Ibid. P-19

${ }^{5}$ Ibid. P- 21
} 
[27] Shah, Ghanshyam: Dalit Identity and Politics, Sage Publications, 2002

[28] Ram, Nandu: The Mobile Scheduled Castes, Hindustan Publishing Corporation, 1988

[29] Singh, K.S: The Scheduled Castes- Vol. I, Oxford University Press, 1993

[30] Raj,M.C: Dalitology, Ambedkar Resource Centre, REDS, 2001

[31] Massey, James: Indigenous People: Dalit, ISPCK, 1998

[32]Zelliot, Eleanor: From Untouchable to Dalit, Manohar, 1992 